\title{
Urban Forestry in Brazilian Amazonia
}

\author{
Thiago Almeida Vieira ${ }^{1, *(1)}$ and Thomas Panagopoulos ${ }^{2, *}$ (C) \\ 1 Institute of Biodiversity and Forests, Federal University of Western of Pará, Santarém 68035-100, Brazil \\ 2 Research Center for Tourism, Sustainability and Well-being, University of Algarve, 8000 Faro, Portugal \\ * Correspondence: thiago.vieira@ufopa.edu.br (T.A.V.); tpanago@ualg.pt (T.P.)
}

Received: 2 March 2020; Accepted: 14 April 2020; Published: 16 April 2020

\begin{abstract}
Urban forests provide multiple benefits in improving people's lives and can be an important tool for achieving the goal of carbon neutral cities. In this study, we analyzed the diversity of plant species from urban forests in cities in the Brazilian Amazonia, based on data from scientific articles, through a systematic literature review. Our analysis revealed that 530 taxa, of which 479 were identified at the species level and 51 at the genus level, covering 38,882 individuals were distributed in 29 cities. The three most frequent species were Ficus benjamina, Mangifera indica, and Licania tomentosa. Exotic species were more frequent than native. The three most frequent species had almost $42 \%$ of the inventoried individuals. The choice of species has been made mainly by the local population, without monitoring by the public authorities. Recommendations for sustainable management of urban forests in Amazonia include investing in training of management bodies, periodic inventories, and awareness actions about the benefits of urban green infrastructure and on the advantages of native species. Policies for the sustainable management of urban green areas are necessary. The municipal governments must continuously monitor indicators of urban ecosystem services and provide financial resources for maintaining and increasing those area rates per person.
\end{abstract}

Keywords: exotic species; urban biodiversity; urban ecosystems; carbon neutral cities

\section{Introduction}

The Amazonia is known worldwide for its forests, mostly of humid ombrophilous type, and for its rivers with clear, dark, or white (muddy) waters, with emphasis on the Amazon River, the largest on the planet. However, their ecosystems are damaged by human action, such as the urbanization process. Until the 1960s, cities in the Brazilian Amazonia were small, often associated with fluvial circulation, with non-modern rural life and few forests explored yet, which gave them strong links to nature [1]. Today, the impacts of urbanization are also observed in this region.

The current form of growth in cities has resulted in losses and degradation of natural ecosystems in urban areas, causing the drastic loss of ecosystem services and low resilience to disturbances, such as those caused by climate change [2]. Among the pressures, there is the large consumption of water for residential and commercial use, damage caused by the generation of waste and its inadequate disposal, expansion over natural areas to meet housing demands, etc. [3], leading to negative impacts on water, air quality, and the maintenance of the habitat of different species [4]. The reality of cities in the Brazilian Amazonia still results from several models of land appropriation, land use, and the linear exploitation of natural capital in this biome [5].

Urban expansion planning must be carried out effectively. One of the aspects to be observed concerns the management of urban green areas. Urban forests, including trees that are not only in woodlands, but also on streets, along streams, and in parks, provide important ecosystem services for urban and peri-urban populations [6]. Trees in cities contribute to the stability of the urban ecosystem [7], provide food [8], and have aesthetic aspects that contribute to the generation of 
economic and social benefits [9]. Urban green spaces are also important for attraction of tourism in city destinations [10]. Urban green infrastructure conserves biodiversity, allows interaction between people, and the contemplation of nature, which helps to break with everyday stress [11]. Trees, for example, are also a way of reducing atmospheric carbon dioxide and for that they need to have their structure maintained [12]. A tree can absorb up to $150 \mathrm{~kg}$ of $\mathrm{CO}_{2}$ per year [13], sequester carbon, and consequently mitigate climate change and contribute to the goal of carbon neutral cities.

In general, studies of urban trees and shrub diversity have largely focused on just one city [14]. Meanwhile, there is need to study this parameter at a regional scale. Knowledge of the patterns of urban species diversity and what can influence them contributes to better planning of conservation actions, especially for the population of trees on the streets of the city [15,16]. A study conducted in the city of Manaus found a positive relationship between socioeconomic variables and the valorization of vegetation in an urban area by the residents of the neighborhood [17]. Thus, we assume as a hypothesis that there is a relationship between the patterns of species diversity of urban forests and the socioeconomic characteristics of cities in the Amazon.

Thus, the aim of this study was to analyze the diversity of urban forest species in the Brazilian Amazonia, relate it to the socioeconomic characteristics of cities, and propose improvements in policy and management of urban green infrastructure.

\section{Materials and Methods}

\subsection{Data Collection}

Scientific articles were the source of data of the diversity of plant species grown in cities of the Brazilian Amazonia, which includes the states of Acre, Amapá, Amazonas, Mato Grosso, Pará, Rondônia, Roraima, and Tocantins and part of Maranhão (also called Legal Amazonia). We conducted a systematic review of the literature based on scientific articles available on international indexing databases (Google Scholar, Scielo, Scopus, and Web of Science). We did additional research in a specialized Brazilian journal-Revista da Sociedade Brasileira de Arborização Urbana (ISSN 1980-7694).

To search for the articles, combinations of keywords were used that indicated the object of study (Urban Forest; Urban Forestry) and the location (Amazonia; Amazon; Acre; Amapá; Amazonas; Maranhão; Mato Grosso; Pará;Rondônia; Roraima; Tocantins). The research was done using the above words in both Portuguese and English. Year of publication of the articles was not delimited. From this, for initial screening, the titles and abstracts were read, and we excluded publications that could not meet the object of this study. Thus, studied articles were selected that contained a number of inventoried individuals and with the respective scientific names. When two or more articles contained the same species list, only the first one was considered.

From public databases, we collected socioeconomic and territorial information from municipalities: population size (number of people) [18]; territorial area $\left(\mathrm{km}^{2}\right)$ [19]; Gross Domestic Product-GDP (provided in Real—R \$, and converted to Euro—€) [20]; Urban Forestry Rate of streets-UFor.R (\%) [21]; Urbanization of Public Roads Rate-UPR (\%) [22]; Human Development Index-HDI (ranges from 0 to 1) [23]; fleet of vehicles of 2018 [24]; temperatures, humidity, and rainfall [25]. The websites of the city halls and/or municipal chamber of each city were consulted to raise the value of finance resources allocated to the management of green areas (consulting the Annual Budget Law of 2019 or the closest available year).

\subsection{Data Analysis}

The scientific names of the species were tabulated with the names of the botanical families and number of individuals inventoried by the studies and verified at Tropicos (www.tropicos.org). All of this information was organized by Amazonian cities. The species were classified as native and exotic according to Flora do Brasil 2020 (http://floradobrasil.jbrj.gov.br/), which provides the origin of native species by phytogeographic domain in Brazil. 
To assess the diversity between cities and to make comparisons between them, the following indices were used. Shannon-Wiener [26], which varies from 0 to Ln of the number of species sampled and determined by the equation:

$$
\mathrm{H}^{\prime}=-\sum \text { pi.Lnpi }
$$

where $\left(\mathrm{H}^{\prime}\right)$ Shannon-Wiener diversity index, (Ln) Napierian logarithm, (pi) ni/N, (ni) number of individuals sampled for each species, and $(\mathrm{N})$ total number of individuals.

The Simpson index, which varies from 0 to 1, was also used, and the higher it is, the greater the probability that individuals are of the same species, that is, greater dominance and less diversity.

$$
\lambda=\sum \mathrm{p}_{\mathrm{i}}{ }^{2}
$$

where $\mathrm{pi}=\mathrm{ni} / \mathrm{N}$, "ni" represents the number of specimens of each species, and " $\mathrm{N}$ " the total number of specimens in the sample.

The relative frequency of each species was calculated by the ratio between the number of individuals of the species and the total number of specimens, multiplied by 100 [27]. The relative density was calculated by the relationship between the number of individuals of one species and the total number of individuals of all species, multiplied by 100 [28].

In order to understand possible influences between socioeconomic variables and ecological parameters of plant species inventoried by studies on urban forests in the Amazon, simple regression analyses were performed between pairs of variables. When necessary, we standardized variables using standard deviation. Principal component analysis was carried out in order to verify climatic similarities between the cities studied. A $t$ test was performed in order to check for differences between the frequency and density of native and exotic species in cities. To verify that socioeconomic variables (population size, Gross Domestic Product, Human Development Index) influence ecological attributes (richness, diversity, and density), a multiple linear regression analysis was performed, as shown in Appendix A. In a second moment, we performed a simple linear regression analysis between variables that presented a significant regression coefficient $(p>0.05)$ in the multiple linear regression analysis [17]. The data were analyzed with the aid of the statistical program $R$ [29].

\section{Results}

\subsection{Urban Forests: Species, Richness, and Diversity}

Were identified 43 scientific articles reporting results about urban forest species richness and diversity, as shown in Appendix B. They were published from 2010 to 2019, covering 29 cities in the nine states of the Brazilian Amazon, as shown in Figure 1. 


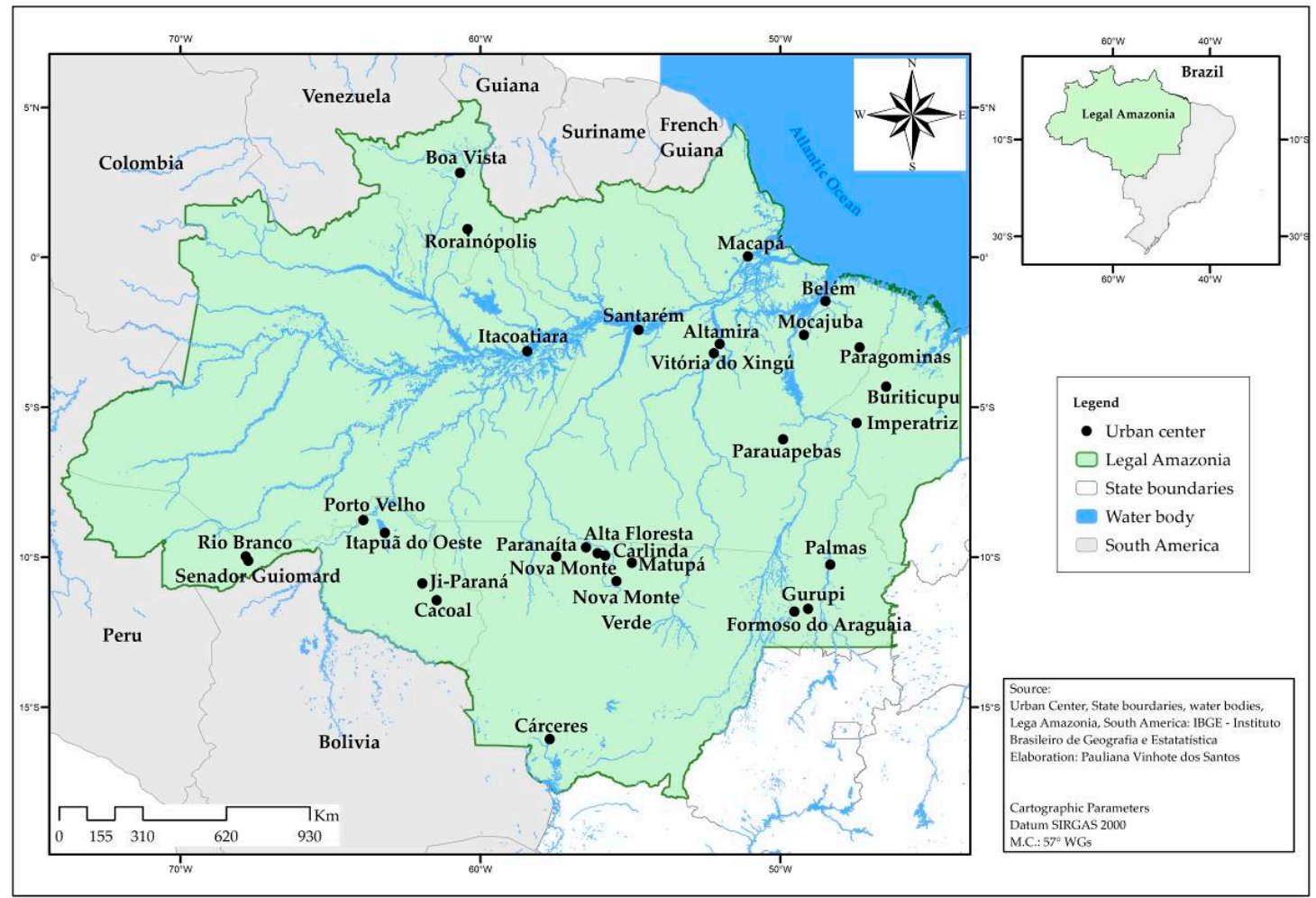

Figure 1. Location of the 29 Brazilian Amazonian cities with scientific articles on urban forestry including data about species diversity.

In total, 530 taxa were cataloged, 479 of which were identified at the species level and 51 only up to genus. Four articles presented species that were not identified at the species level, nor the genus. One study grouped five individuals into "other species". The species belong to 71 botanical families, with Fabaceae having a greater number of species, as shown in Table 1. The Chrysobalanaceae family presented only five species, but together they registered 8281 individuals.

Table 1. Main botanical families, number of species, and individuals reported in studies on urban forestry in 29 cities of Brazilian Amazonia.

\begin{tabular}{ccc}
\hline Family & Number of Species & Number of Individuals \\
\hline Fabaceae & 151 & 5997 \\
Arecaceae & 46 & 2478 \\
Bignoniaceae & 33 & 2411 \\
Myrtaceae & 26 & 3202 \\
Malvaceae & 27 & 1363 \\
Moraceae & 21 & 4852 \\
Anacardiaceae & 17 & 4578 \\
Rutaceae & 16 & 444 \\
Apocynaceae & 14 & 178 \\
Rubiaceae & 12 & 488 \\
\hline
\end{tabular}

Of the species reported in studies on urban forestry in the Brazilian Amazon, the most frequent were Ficus benjamina and Mangifera indica (86.2\% of cities) and Licania tomentosa $(82.8 \%)$, as shown in Figure 2. These three species are also the ones with the highest density of individuals reported in the urban green areas studied in the articles, with L. tomentosa presenting 8018 individuals, which represents $20.6 \%$ of all individuals inventoried in the studies of the 29 cities. 


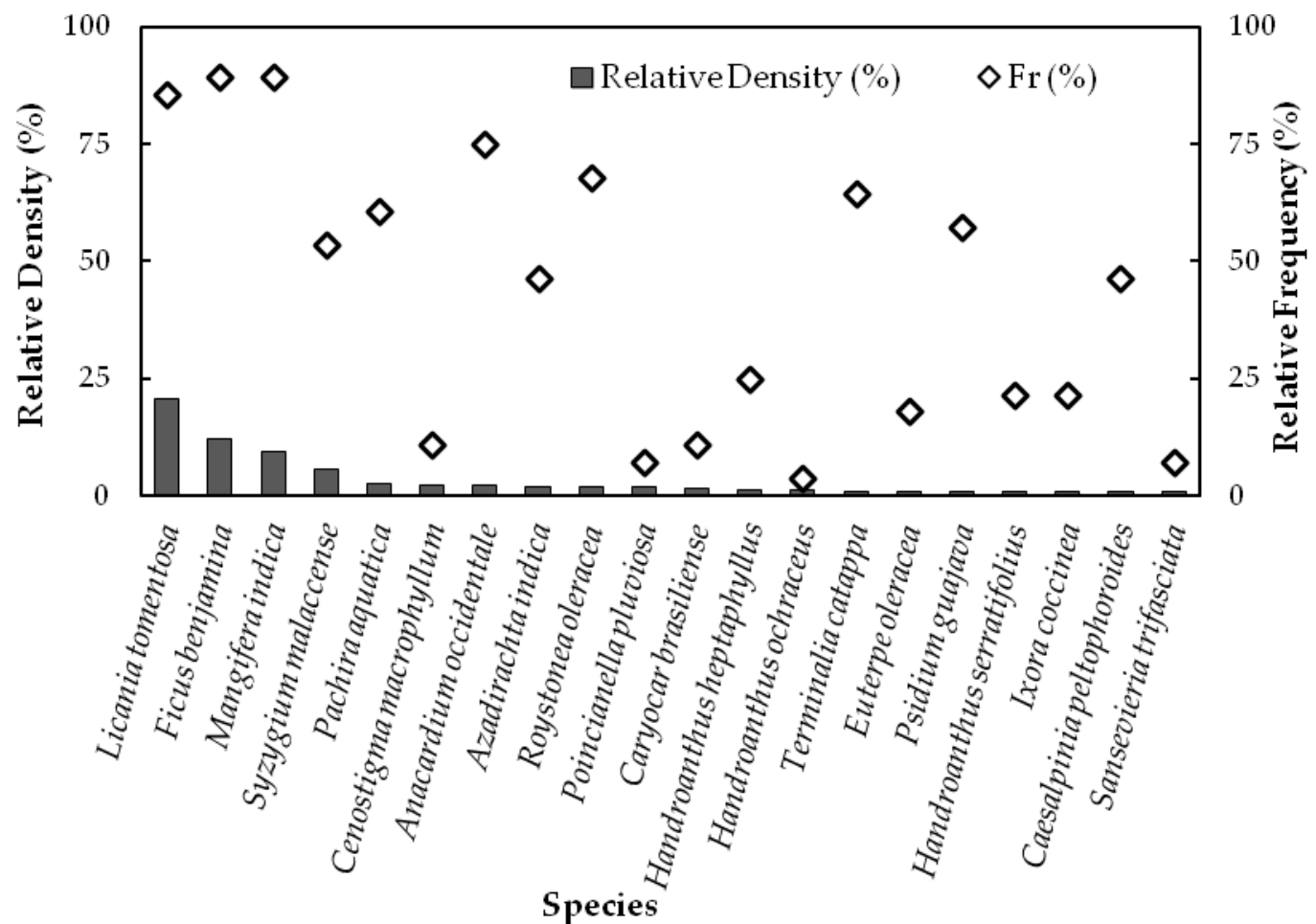

Figure 2. Density and relative frequency of the main plant species grown in urban forests in 29 cities of Brazilian Amazonia.

The average richness was 43.1 plant species per city, inventoried in scientific studies. The average density among the studies was approximately 1341 individuals per city. When analyzing the richness of species and number of individuals per city, it appears that the city of Rio Branco presented the greatest inventoried richness (179 species) and Boa Vista the highest number of individuals cataloged (6913), as shown in Figure 3. Belém and Itacoatiara had only one species studied by the articles.

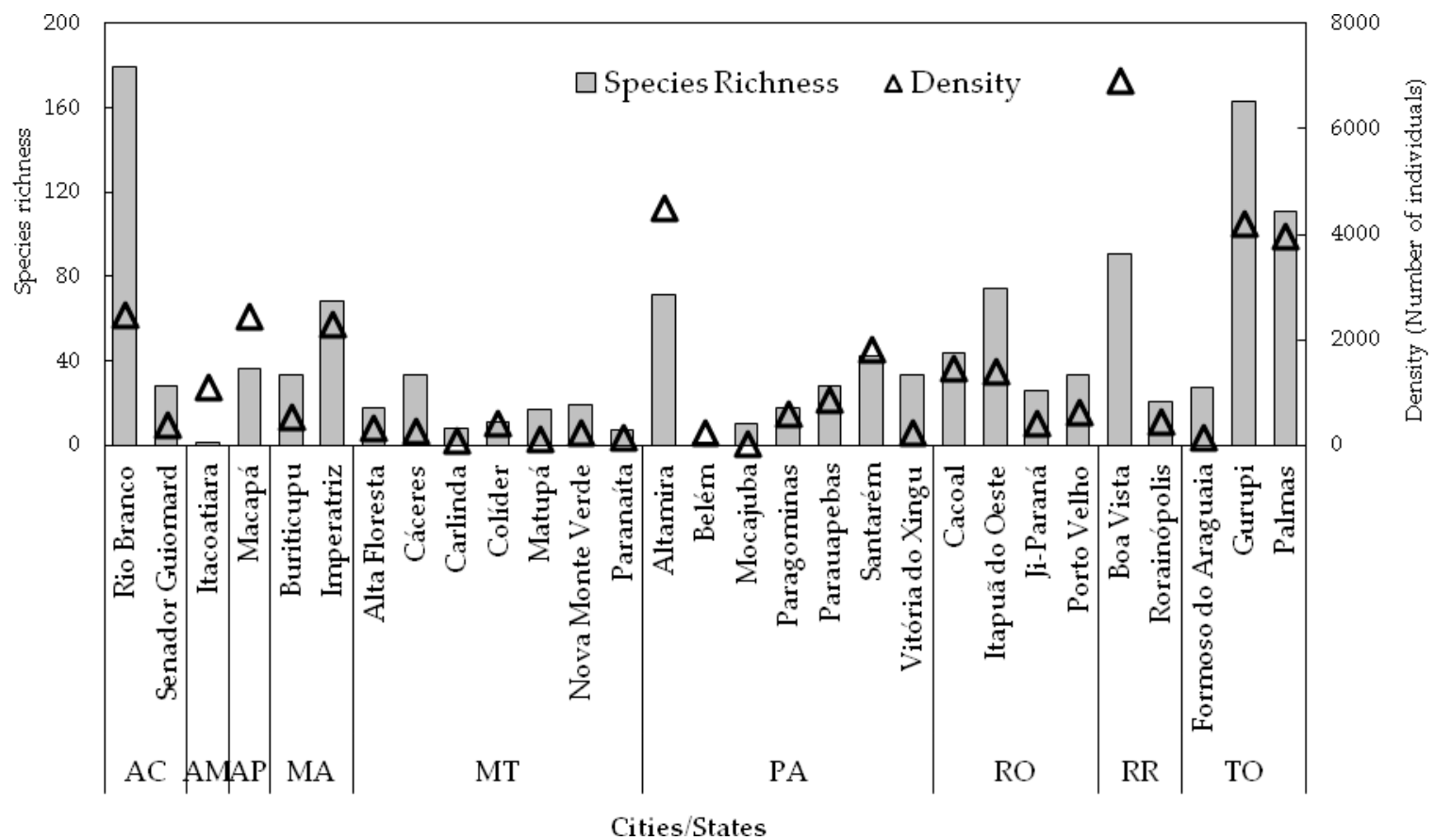

Figure 3. Species richness and number of individuals in urban forestry of 29 cities of Amazonia. 
The average diversity among the 29 cities was $2.082\left(\mathrm{H}^{\prime}\right)$, with the city of Rio Branco presenting a greater diversity of species $\left(\mathrm{H}^{\prime}=4.183\right)$, followed by Palmas $\left(\mathrm{H}^{\prime}=3.524\right)$ and Itapuã do Oeste $\left(\mathrm{H}^{\prime}=3.167\right)$. These three cities also obtained the lowest values for the Simpson Index $(0.0271 ; 0.0525$; 0.090, respectively), confirming a high diversity of plants in the urban forests of these cities.

Among the identified species, $34.7 \%$ are exotic and $65.3 \%$ are native to Brazil. Among the native ones, $68.7 \%$ occur in the Amazon and also in other Brazilian biomes, and 14.1\% have the Amazon as their only phytogeographic domain. On urban forestry of the cities studied, the average richness of exotic plant species was 9.4 and of native species was 7.7. In these 29 cities, there was a higher relative frequency of exotic species, as shown in Figure 4. Regarding the number of individuals of each species by origin, there was no significant difference between cities.

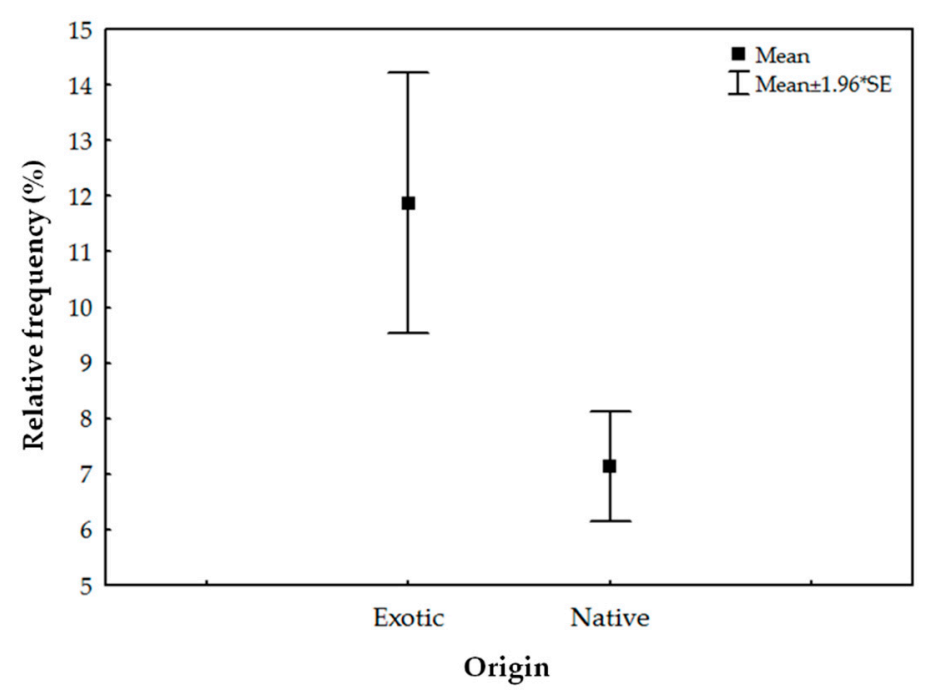

Figure 4. The $t$ test for relative frequency of native and exotic plant species in urban forestry in the Brazilian Amazonia.

\subsection{Socioeconomic and Climatic Characteristics}

The 29 municipalities studied by the articles of urban forestry have a territorial area ranging from $871 \mathrm{~km}^{2}$ (Mocajuba) to $159,533 \mathrm{~km}^{2}$ (Altamira), with an average of $14,005 \mathrm{~km}^{2}$. The population average was 187,066 people, with the city of Nova Monte Verde having the lowest number of people and Belém the largest, as shown in Table 2. The budgets for the creation and/or maintenance of urban green areas were on average $2,414,530.105 €$, which represents $5.8 €$ per inhabitant/year. Information from two cities was missing.

The number of vehicles in the 29 cities is 2,320,963 and together, these cities had 38,882 individuals of plant species inventoried. We understand that the studies carried out sampling, but to arrive at the proportion of a tree or shrub for each car, 59.7 times the number of inventoried plants would be needed. City halls raise funds from tax collection to provide improvements in the infrastructure of cities, including urban green areas. In this sense, it is important to highlight that the Federal Constitution of Brazil provides that $50 \%$ of the collection of taxes from the ownership of licensed motor vehicles belongs to the municipalities where the vehicles are licensed [30]. Belém was the city with the largest fleet of vehicles $(451,776)$, with one vehicle per 3.3 inhabitants. However, the city of Alta Floresta has a higher proportion of vehicles per inhabitant, with one vehicle per 1.2 people. 
Table 2. Territorial, social, and demographic characteristics of 29 Brazilian Amazonian cities with studies on urban forestry.

\begin{tabular}{|c|c|c|c|c|c|c|c|c|}
\hline Brazil States (acronyms) & Cities & $A\left(\mathbf{k m}^{2}\right)$ & UPR \% & UFor.R \% & Population & GDP/person & HDI & Fleet \\
\hline \multirow{2}{*}{ Acre $(\mathrm{AC})$} & Rio Branco & 8834.94 & 20.4 & 13.8 & 407,319 & 4623.10 & 0.727 & 179,395 \\
\hline & Senador Guiomard & 2322.03 & 4.2 & 13.3 & 23,024 & 3468.30 & 0.640 & 6501 \\
\hline Amazonas (AM) & Itacoatiara & 8891.91 & 11.9 & 57.9 & 101,337 & 4476.52 & 0.644 & 23,368 \\
\hline Amapá (AP) & Macapá & 6563.85 & 8.8 & 66 & 503,327 & 4304.46 & 0.733 & 152,475 \\
\hline \multirow{2}{*}{ Maranhão (MA) } & Buriticupu & 2544.86 & 0.1 & 59.4 & 72,358 & 1476.72 & 0.556 & 16,164 \\
\hline & Imperatriz & 1368.99 & 22.4 & 69.7 & 258,682 & 5897.64 & 0.731 & 152,881 \\
\hline \multirow{7}{*}{ Mato Grosso (MT) } & Alta Floresta & 8953.19 & 3 & 37.7 & 51,782 & 6786.22 & 0.714 & 44,699 \\
\hline & Cáceres & $24,593.12$ & 23.2 & 79.2 & 94,376 & 4058.20 & 0.708 & 49,271 \\
\hline & Carlinda & 2416.14 & 0 & 34.8 & 10,305 & 3328.32 & 0.665 & 5136 \\
\hline & Colíder & 3103.96 & 7.1 & 83.6 & 33,438 & 5821.51 & 0.713 & 23,878 \\
\hline & Matupá & 5219.03 & 1.1 & 16.3 & 16,566 & 8372.36 & 0.716 & 11,156 \\
\hline & Nova Monte Verde & 5150.56 & 1.7 & 25.5 & 9178 & 4197.79 & 0.691 & 4468 \\
\hline & Paranaíta & 4796.01 & 1.8 & 92.8 & 11,225 & 8011.01 & 0.672 & 6669 \\
\hline \multirow{7}{*}{ Pará (PA) } & Altamira & $159,533.33$ & 22.7 & 44.3 & 114,594 & 4826.70 & 0.665 & 61,868 \\
\hline & Belém & 1059.46 & 36.1 & 22.3 & $1,492,745$ & 4366.95 & 0.746 & 451,776 \\
\hline & Mocajuba & 871.17 & 0 & 19.7 & 31,136 & 2012.23 & 0.575 & 1830 \\
\hline & Paragominas & $19,342.57$ & 5.1 & 12.9 & 113,145 & 5270.45 & 0.645 & 41,564 \\
\hline & Parauapebas & 6886.21 & 21.8 & 30.5 & 208,273 & $9,546.46$ & 0.715 & 91,669 \\
\hline & Santarém & $17,898.39$ & 7.8 & 43.3 & 304,589 & 3332.92 & 0.691 & 102,101 \\
\hline & Vitória do Xingu & 3089.54 & 2.4 & 73.4 & 15,134 & $4,922.76$ & 0.596 & 2459 \\
\hline \multirow{4}{*}{ Rondônia (RO) } & Cacoal & 3792.89 & 11.7 & 86.6 & 85,359 & 4749.09 & 0.718 & 66,914 \\
\hline & Itapuã do Oeste & 4081.58 & 0 & - & 10,458 & 3251.61 & 0.614 & 3068 \\
\hline & Ji-Paraná & 6896.65 & 6.4 & 17.3 & 128,969 & 4879.70 & 0.714 & 92,828 \\
\hline & Porto Velho & $34,090.95$ & 21.7 & 40 & 494,013 & 6188.08 & 0.736 & 276,601 \\
\hline \multirow{2}{*}{ Roraima (RR) } & Boa Vista & 5687.04 & 4.3 & 47.5 & 399,213 & 5333.16 & 0.752 & 190,870 \\
\hline & Rorainópolis & $33,579.74$ & 5.8 & 23.7 & 30,163 & 3913.10 & 0.619 & 6132 \\
\hline \multirow{3}{*}{ Tocantins (TO) } & Formoso do Araguaia & $13,423.38$ & 1.4 & 96.9 & 18,440 & 4239.82 & 0.670 & 7300 \\
\hline & Gurupi & 1836.09 & 0.4 & 88.7 & 86,647 & 5158.13 & 0.759 & 60,893 \\
\hline & Palmas & 2218.94 & 31.3 & 79.9 & 299,127 & 6217.63 & 0.788 & 187,029 \\
\hline
\end{tabular}

Note: $\mathrm{A}=$ area; UPR = Urbanization of Public Roads Rate; UFor.R = Urban Forestry Rate; Population; GDP = Gross Domestic Product in euros; HDI = Human Development Index; Fleet $=$ Fleet of vehicles; $1.00 €=4.66 \mathrm{R} \$$, in February, 052020. 
The average minimum and maximum temperatures in cities were 25.9 and $27.1{ }^{\circ} \mathrm{C}$, respectively. The average minimum humidity was $72 \%$ and the maximum was $77.4 \%$. The annual rainfalls of cities ranged from 373.40 to $4208 \mathrm{~mm}$, with an average of $1717.03 \mathrm{~mm}$, showing favorable conditions for the establishment of tropical plants. Brazil's climate does not impose many restrictions on the adaptation of plant species in the urban space, especially to native species. Cities were similar in terms of environmental conditions and are grouped by these similarities, as shown in Figure 5.

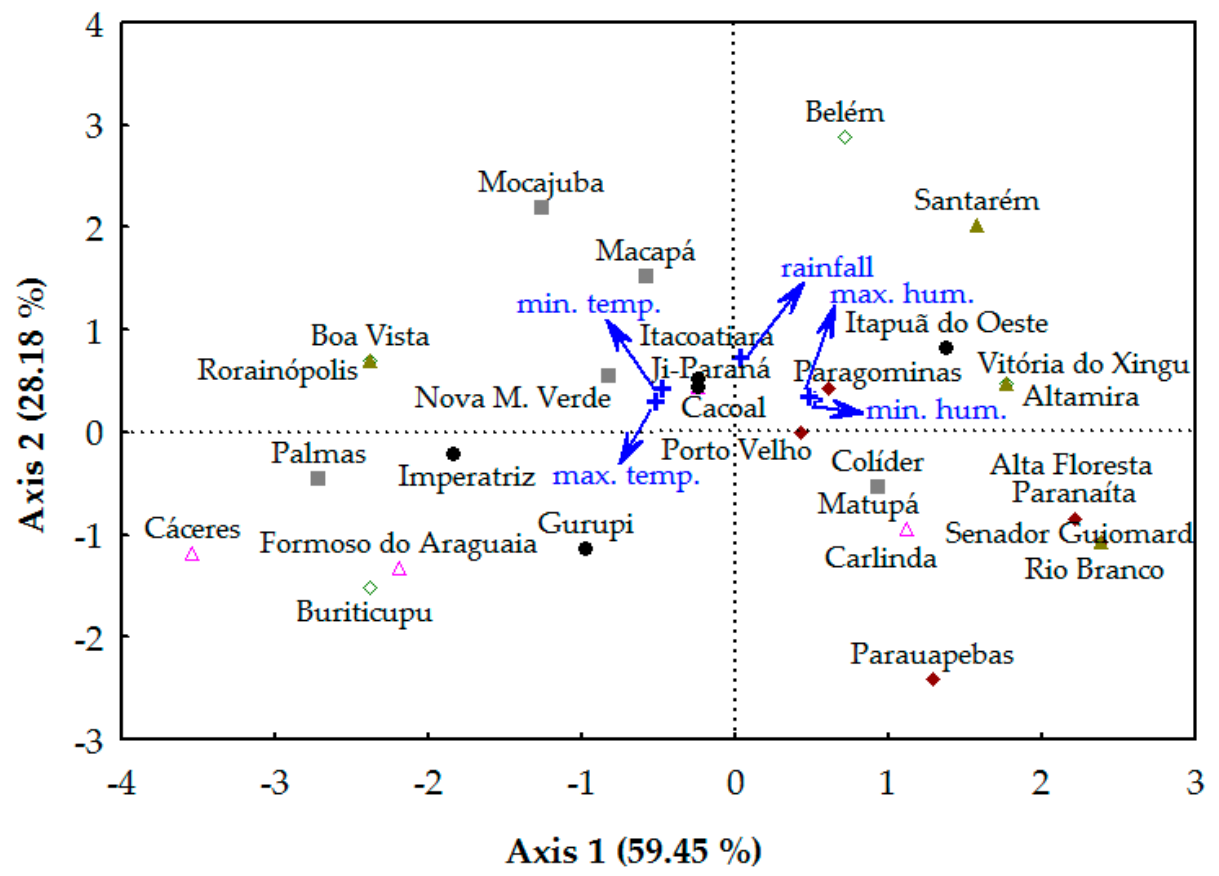

Figure 5. Principal component analysis (PCA) demonstrating climatic similarities between the 29 cities with studies on urban forestry in the Brazilian Amazonia. Note: min. temp. = minimum temperature; $\max$. temp. = maximum temperature; $\min$. hum. = minimum humidity; $\max$. hum. $=$ maximum humidity.

The average rate of tree-lined roads in cities was $49.2 \%$ and ranged from $12.9 \%$ (Paragominas) to 96.9\% in Formoso do Araguaia. The average Urbanization of Public Roads Rate was 10\%, and Belém was the city with higher urbanization of its streets (36.1\%).

The studies about urban forestry were carried out in 29 cities in the Brazilian Amazonia, which among them still have cities with a zero urbanization rate of public roads and the highest rate is $36.1 \%$ (Belém), as shown in Table 2. This parameter is calculated by the Brazilian Institute of Geography and Statistics [22] and indicates the percentage of households located on paved streets. Formoso do Araguaia, a city with a higher rate of tree lined in roads (Urban Forestry Rate-UFor.R), allocates around $33.90 € /$ person/year for carrying out environmental management in the municipality, almost 6 times more than the average of 29 cities.

Among the socioeconomic and ecological variables, the Human Development Index of the cities had a significant influence on ecological variables of richness and density, as shown in Figure 6A,B. 

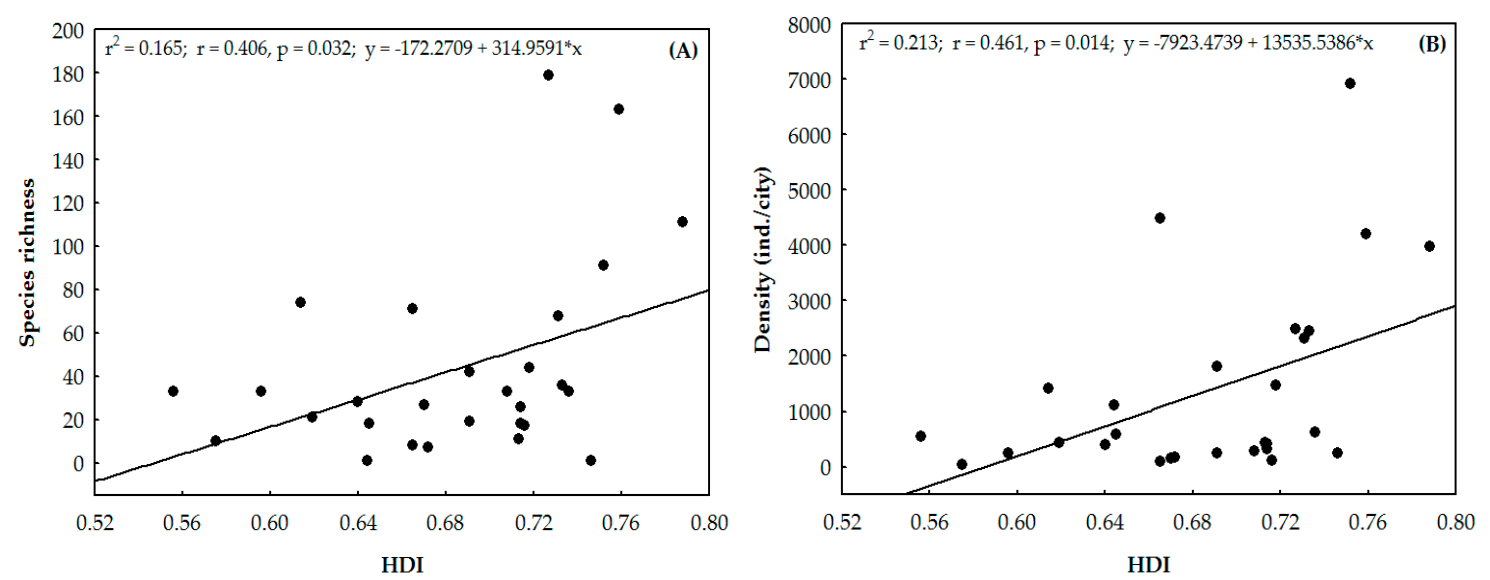

Figure 6. Linear regression analysis between the Human Development Index (HDI), density (A), and richness of species (B) vegetation inventoried on urban forestry by studies in the Brazilian Amazonia.

\section{Discussion}

The results revealed that in 29 Amazonian cities, the exotic species were more frequent than the native. Besides, the three most frequent species had almost $42 \%$ of the inventoried individuals. The local population act in the design of urban forests, but without necessary monitoring by the public authorities. Results exposed that research on urban forestry in the Amazon is recent (last decade). The number of articles published in scientific journals seems to be low and shows under publication. Although it is known that there is a high number of research works at concluding undergraduate courses, and even at a master's and doctorate level, most have not been published as articles in scientific journals. Research results that are not published in scientific journals can limit access to information by other researchers, making knowledge of scientific evidence unfeasible [31].

Brazilian legislation supports the creation and maintenance of urban green areas. The Brazilian Constitution provides that urban complexes and sites of landscape value constitute Brazilian cultural heritage and that everyone has the right to an ecologically balanced environment, and for this, public authorities and the community have a role in defending and preserving [30]. In addition, for the protection and management of urban green areas, the 2012 Brazilian Forest Code provides that city halls may require green areas in allotments, commercial enterprises, and in the implementation of infrastructure in cities.

Brazilian States have to take actions that guarantee a healthy urban environment. Urban forestry may play a key role in sequestering carbon emissions in cities. A study carried out in a city in China, between 2004 and 2006, showed that the average annual emissions of $C$ by the combustion of fossil fuels was 11.16 million tons, with the $C$ stored by the urban forests of this city corresponding to $3.02 \%$ of annual average $\mathrm{C}$ emissions [32].

Studies about urban forestry in the Brazilian Amazonia have shown that people have been primarily responsible for planting and cultivating plant species located on the streets $[28,33]$. In this sense, the municipal government needs to prioritize the planning of actions related to urban forestry. Considering these people's actions on the composition and management of the species, the preference for F. benjamina and L. tomentosa occur because they form leafy tops and provide shade throughout the year, being species of rapid growth and easy adaptation to the urban environment [34].

Additionally, the three most frequent species are also the ones with the highest relative density, so that together they account for almost $42 \%$ of all individuals inventoried by studies on forest ballots in the Brazilian Amazonia. The use of the species L. tomentosa, as shown in Figure 7, that produces edible fruits of high nutritional value [35], can increase city resilience in times of crisis. Meanwhile, this was considered disproportionate in a study carried out in three cities of Mato Grosso [27] and for this reason the authors recommended the introduction of new shrub and tree species native to the region in the urban green spaces studied. 


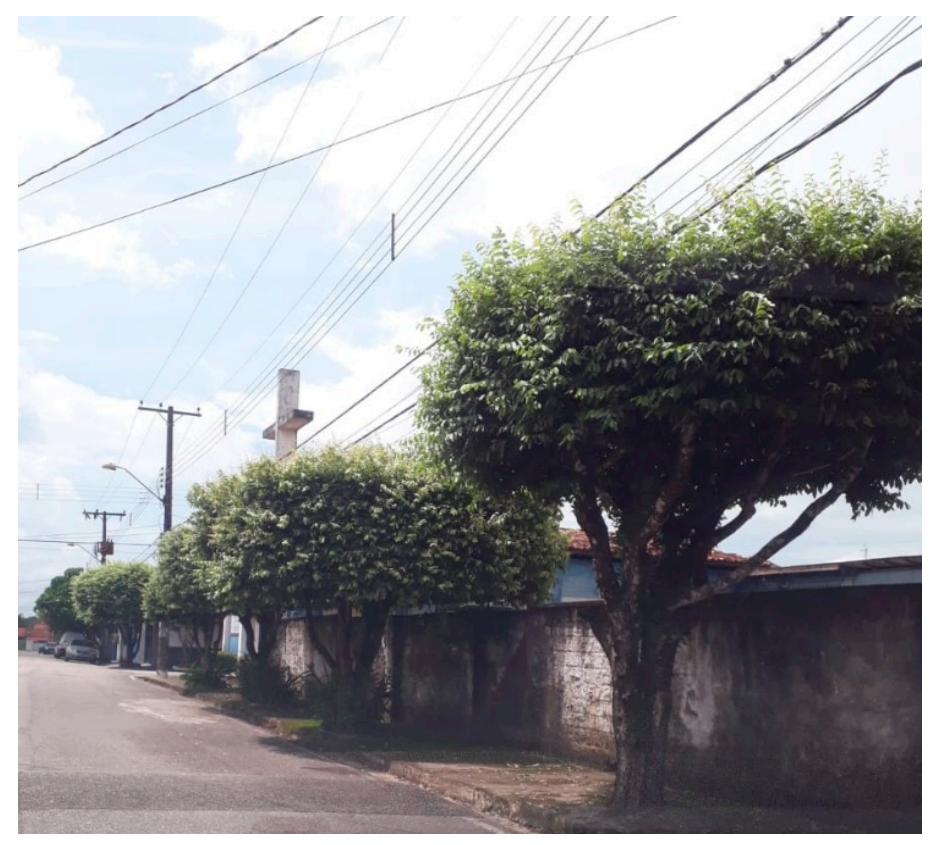

Figure 7. Licania tomentosa cultivated in Belém streets, Brazilian Amazonia. Photo: Vieira, L.A.

On the other hand, it is interesting to note that 129 species inventoried in urban forestry in 29 cities were represented by only one individual. This shows disproportionality in almost $25 \%$ of the species grown in these areas. This was pointed out as a problem for urban forestry by research carried out in cities in the state of Mato Grosso [27,36].

Plants that occupy urban space are more propitious to attack by plagues and diseases as a result of the anthropized environment, and greater diversity can reduce the risks to plant health of these plants [37]. In this sense, in order to increase the diversity of plant species, it is recommended not to plant more than $10 \%$ of any species; no more than $20 \%$ of any genus; and no more than $30 \%$ of any botanic family [38].

In general, there is a lack of specific legislation to address the creation, management, and maintenance of urban green areas in municipalities. However, it should be noted that the city of Belém, capital of the state of Pará, instituted Municipal Law No. 8909, of March 29, 2012, which resulted in a Technical Guidance Manual for Urban Forestry in Belém [39]. This lack of legislation can contribute to irregular distribution among plant species [27], often resulting in inadequate attitudes by residents and even public managers, who have little technical information on urban green areas [40].

It was reported that plants were poorly distributed geographically in the city of Vitória do Xingu, and that the central region is more wooded than the peripheral ones, demonstrating the lack of planning by the government [41]. The urban forest can help environmental balance, such as sequestering carbon, but it is necessary that the technicians and the population understand that the planting must consider the correct species in the right place, in order to reduce early tree mortality, optimize ecosystem services, and maintain biodiversity [12].

The adoption of species by the population also occurs, in part, as a reflection of old landscape trends, because from the aesthetic point of view, species of great beauty were distributed all over the world, and not only in a geographical or restricted vegetal formation, so the choice for many exotic species resulted [42]. This trend dates back to the Brazilian colonial period, when propagules of plant species from all over the world were collected to be cultivated in botanical gardens and therefore, even today, native species seem to be a secondary element in the urban landscape [43].

Exotic species can have a high capacity for adaptation in non-native environments, competing for resources (light, water, and nutrients), inhibiting the growth of native species, being potentially toxic to local fauna [44], and can present invasive species behavior [45,46]; directly affecting biodiversity, 
the economy, and human health [47]. The priority for exotic species ends up disregarding the native's potential [48]. The cultivation of native species is technically recommended in order to guarantee the co-evolutionary ecological and genetic relationships, of dispersal of propagules (pollen and seeds), involving fauna and flora, within the urban environment and also for the conservation of native genetic material [46]. In addition, aesthetically, a wooded city with species characteristic of its region, would make the urban environment unique, with differentiated aspects from other cities and much more attractive [48].

Considering the importance of urban forestry, we mention that an inventory of the afforestation of the city of Altamira (PA) was carried out, through a partnership between the City Hall, higher education institutions, and the Public Ministry [28]. The results showed a great presence of exotic species, and for that reason, actions of production of seedlings of native species have been carried out for cultivation in the urban forestry of this city, such as Handroanthus serratifolius, Andira parviflora, and Clitoria racemosa.

Bifurcation at low heights is a problem reported by the articles, as it makes it difficult for pedestrians to move on sidewalks [49-51]. For these cases, it is recommended that the crown be lifted, an intervention that aims to suppress the lower branches [49]. Damage to the sidewalks caused by plant roots was mentioned, in general due to the little space available for root growth and the improper choice of the species considering this space $[28,52,53]$, or by soil conditions, which were generally compacted [54].

In many cases, plants considered inadequate in the occupied urban green space must be replaced, especially those that are generating more disservices than benefits [55]. However, this measure must be well grounded and planned. Based on a technical report from the environmental agency, suppression can be authorized in cases of danger of falling or of increasing and irreversible damage to property; due to the irrecoverable phytosanitary state; or when it is dead [39]. The spacing between plants, area free of pavement, need for staking and protection grids, and soil available for each plant should follow adequate arboriculture techniques [56].

These results show that the selection of species to be cultivated in Amazonian urban streets is a priority. This choice must meet the demand for shade (related to the canopy architecture and the deciduous behavior of the species) and contribute to the thermal comfort and well-being of the population [43]. The selection of species made by people in the cities studied shows that there is interest in shade and fruit production, such as Mangifera indica, Syzygium malaccense, Anacardium occidentale, Euterpe oleracea, Psidium guajava, etc. Although fruit species are of importance to the human population and attractive to avifauna, planting these species on sidewalks should be avoided, as these fruits can cause damage to vehicles and pedestrians circulating on the site, for this, one must choose species that do not produce large and fleshy fruits [39].

Our study showed the plant diversity in urban forests in 29 cities. Meanwhile, most studies in the Brazilian Amazonia focus their results in problems related to urban forests. Among the tree maintenance difficulties mentioned were reports of phytosanitary problems (diseases and insect attacks), mechanical injuries in some part of the plant (usually in the bark of the stem), and presence of hemiparasites. Problems related to infrastructure were conflicts caused by deficient crown and root maintenance, damage on the sidewalks due to lack of adequate space for root growth, crown conflicts with electric cables, bifurcated individuals at short heights, and incorrect pruning. On the other hand, urban trees provide multiple ecosystem services and contribute to the improvement of people's quality of life and to the balance of the urban environment.

\section{Human Development Index Influencing the Plant Density and Richness}

As mentioned above, we showed there is a correlation between density and diversity of urban tree species and the Human Development Index (HDI) of the Amazonian cities. The positive correlation indicates that cities with higher human development indexes have higher values of plant diversity and density in urban forests. In our study, 15 cities have an HDI considered as high (0.700-0.799). In these 
cities, the average plant density in urban forests was 1808 inventoried plants and the average richness was 57 species/city. The other 14 cities had an average HDI (0.550-0.699) and the average density was 840 inventoried plants and a richness of 28 species/city.

The HDI is an important social metric and highlights that sustainability has to be based on the rationale that high human development facilitates sustainable development [57]. A research of sub-Saharan African cities revealed that one of the barriers to the sustainable delivery of ecosystem services is social inequality and urban planning [58]. In Central Asia, the Human Development Index is high in countries with an urbanization level over 70 percent, and probably, a higher socio-economical level leads to larger interest for environmental and sustainable solutions among society [59]. A study about environmental justice in accessibility to green infrastructure in two European cities show that deprived neighborhoods with minorities had less availability to quality green spaces [60].

A study in 100 cities around the world, including four Brazilian cities (Curitiba, São Paulo, Porto Alegre, and Manaus), highlighted that the more affluent cities tend to have a greater biomass of vegetation, involving the maintaining of larger areas of vegetation and larger tree populations in streets [61]. Plant diversity may reflect social, economic, and cultural influences. In Arizona city, a study aimed to investigate the influence of biotic, abiotic, and human-related variables with richness of perennial plants (including both exotic and native) and showed that plant diversity at higher income neighborhoods was on average twice that found in the landscapes of less wealthy areas [62]. Thus, municipalities with a low Human Development Index should adopt policies for viable and diverse urban forests, providing knowledge to the population and aiming at well-being for society.

\section{Conclusions and Recommendations}

Investments should be made in research on species suitable for urban forestry in Amazonian cities. It is expected that there will be an appreciation of native species, aiming to increase their diversity in the urban environment, seeking, in them, positive characteristics, not only of aesthetic parameters, but functional. In this sense, considering that the capacity of species to transform $\mathrm{CO}_{2}$ into biomass, through photosynthesis, in urban green areas has been little studied [31], we recommend future research to investigate the potential of this transformation by the species used in urban forestry in the Brazilian Amazonia.

Investments should be made in periodic surveys and systematization of information on plant individuals in urban forestry, through continuous inventories. Thus, the performance of forestry professionals should be valued, and who must compose teams for planning, management, and monitoring of urban forestry. It is important that municipalities periodically monitor indicators for urban forestry, in order to optimize the financial resources invested in these areas, as well as to achieve the objectives of ecosystem services and other benefits of trees in cities.

Professionals must also consider the concept of green infrastructure, involving environmental strategies based on multidisciplinary teams of forestry, architecture, construction, and urbanism, aiming at sustainability in cities. Urban trees provide numerous ecosystem services to both inhabitants and visitors, thus local authorities should consider how to plan, manage, and promote urban green infrastructure as part of the tourism offer [63].

It is necessary that the teams of the management bodies are trained to manage these areas sustainably and improve the social perception of biodiversity and the importance of sustainable development. Different strategies should be performed to promote the sustainable use of trees in the cities, including land stewardship, and involving civil society in conservation based on environmental volunteering. Through environmental education actions, the population must be aware of the role of urban green infrastructure, especially the native species, and how citizens can contribute to the conservation of urban forestry in the Brazilian Amazonia.

Finally, city halls and city councils must make efforts to establish study committees that propose policies for the management of urban green areas in the cities under their jurisdiction. In addition, it is important that annual budgets provide for financial resources for the maintenance and restoration 


\section{Appendix B}

Table A2. List of articles consulted on urban forestry in Brazilian Amazonia.

\begin{tabular}{|c|c|c|c|c|}
\hline Article titles & Authors & Journal & Year & Link to Access \\
\hline $\begin{array}{l}\text { Inventário e diagnóstico da arborização urbana } \\
\text { viária de Rio Branco, AC }\end{array}$ & Paiva, A.V., et al. & $\begin{array}{l}\text { Revista da Sociedade Brasileira de } \\
\text { Arborização Urbana }\end{array}$ & 2010 & https://revistas.ufpr.br/revsbau/article/view/66256 \\
\hline $\begin{array}{l}\text { Análise da arborização urbana de três cidades da } \\
\text { região norte do Estado de Mato Grosso }\end{array}$ & $\begin{array}{l}\text { Almeida, D.N.; } \\
\text { Rondon Neto, R.M. }\end{array}$ & Acta Amazonica & 2010 & http://www.scielo.br/pdf/aa/v40n4/v40n4a03 \\
\hline $\begin{array}{l}\text { Análise da arborização urbana de duas cidades da } \\
\text { região norte do estado de Mato Grosso }\end{array}$ & $\begin{array}{l}\text { Almeida, D.N.; } \\
\text { Rondon Neto, R.M. }\end{array}$ & Revista Árvore & 2010 & https://www.redalyc.org/pdf/488/48815860015.pdf \\
\hline $\begin{array}{l}\text { Diagnóstico da arborização urbana da cidade de } \\
\text { Cacoal-RO }\end{array}$ & $\begin{array}{l}\text { Almeida, J.R.; } \\
\text { Barbosa, C.G. }\end{array}$ & $\begin{array}{l}\text { Revista da Sociedade Brasileira de } \\
\text { Arborização Urbana }\end{array}$ & 2010 & https://revistas.ufpr.br/revsbau/article/view/66239 \\
\hline $\begin{array}{l}\text { Levantamento censitário da arborização urbana } \\
\text { viária de Senador Guiomard, Acre }\end{array}$ & Maranho, A.S., et al. & $\begin{array}{l}\text { Revista da Sociedade Brasileira de } \\
\text { Arborização Urbana }\end{array}$ & 2012 & https://revistas.ufpr.br/revsbau/article/view/66532 \\
\hline $\begin{array}{l}\text { The floristic composition of urban afforestation of } \\
\text { the city Altamira, Pará State, Brazil. }\end{array}$ & Parry, M.M., et al. & $\begin{array}{l}\text { Revista da Sociedade Brasileira de } \\
\text { Arborização Urbana }\end{array}$ & 2012 & $\begin{array}{l}\text { https://revistas.ufpr.br/revsbau/article/download/ } \\
66550 / 38357\end{array}$ \\
\hline $\begin{array}{l}\text { Diagnóstico quali-quantitativo da arborização das } \\
\text { praças do município de Altamira, Pará }\end{array}$ & Souza, O.P.S., et al. & Enciclopédia Biosfera & 2013 & $\begin{array}{l}\text { http://www.conhecer.org.br/enciclop/2013b/ } \\
\text { CIENCIAS\%20AGRARIAS/diagnostico\%20quali. } \\
\text { pdf }\end{array}$ \\
\hline $\begin{array}{l}\text { A arborização pública e a eficiência do } \\
\text { sombreamento da superfície urbana em bairros } \\
\text { residenciais de Porto Velho, RO }\end{array}$ & Santos, J.A., et al. & $\begin{array}{l}\text { Revista da Sociedade Brasileira de } \\
\text { Arborização Urbana }\end{array}$ & 2013 & https://revistas.ufpr.br/revsbau/article/view/66440 \\
\hline $\begin{array}{l}\text { Fitossociologia e diversidade de espécies arbóreas } \\
\text { das praças centrais do município de Gurupi-TO }\end{array}$ & $\begin{array}{l}\text { Santos, A.F.; José, } \\
\text { A.C.; Sousa, P.A. }\end{array}$ & $\begin{array}{l}\text { Revista da Sociedade Brasileira de } \\
\text { Arborização Urbana }\end{array}$ & 2013 & https://revistas.ufpr.br/revsbau/article/view/66511 \\
\hline $\begin{array}{l}\text { Diversidade em uma área verde urbana: avaliação } \\
\text { qualitativa da arborização do campus da } \\
\text { Universidade Federal do Acre. Brasil }\end{array}$ & $\begin{array}{l}\text { Maranho, A.S.; } \\
\text { Paula, S.R.P. }\end{array}$ & RevistaAgro@mbiente On-Line & 2014 & $\begin{array}{l}\text { https: } \\
\text { //revista.ufrr.br/agroambiente/article/view/1868 }\end{array}$ \\
\hline $\begin{array}{l}\text { Quantitative survey of afforestation of squares in } \\
\text { the city of Cáceres, Mato Grosso State, Brazil }\end{array}$ & Assunção, K.C., et al. & $\begin{array}{l}\text { Revista da Sociedade Brasileira de } \\
\text { Arborização Urbana }\end{array}$ & 2014 & https://revistas.ufpr.br/revsbau/article/view/66598 \\
\hline $\begin{array}{l}\text { Levantamento quali-quantitativo de espécies } \\
\text { arbóreas e arbustivas na arborização urbana do } \\
\text { município de Paranaíta, Mato Grosso }\end{array}$ & Mamede, J.S.S., et al. & Biodiversidade & 2014 & $\begin{array}{l}\text { http://periodicoscientificos.ufmt.br/ojs/index.php/ } \\
\text { biodiversidade/article/view/1956/1452 }\end{array}$ \\
\hline $\begin{array}{l}\text { Espécies empregadas na arborização urbana do } \\
\text { bairro Santiago, Ji-Paraná/RO }\end{array}$ & $\begin{array}{l}\text { Santos, J.A.; } \\
\text { Costa, L.M. }\end{array}$ & $\begin{array}{l}\text { Revista da Sociedade Brasileira de } \\
\text { Arborização Urbana }\end{array}$ & 2014 & https://revistas.ufpr.br/revsbau/article/view/66595 \\
\hline $\begin{array}{l}\text { Inventário quali-quantitativo da arborização viária } \\
\text { de um trecho da rodovia PA- } 275 \text { no município de } \\
\text { Parauapebas-PA }\end{array}$ & Ferro, C.C.S., et al. & $\begin{array}{l}\text { Revista da Sociedade Brasileira de } \\
\text { Arborização Urbana }\end{array}$ & 2015 & https://revistas.ufpr.br/revsbau/article/view/63071 \\
\hline
\end{tabular}


Table A2. Cont.

\begin{tabular}{|c|c|c|c|c|}
\hline Article titles & Authors & Journal & Year & Link to Access \\
\hline $\begin{array}{l}\text { A geotecnologia como ferramenta para o } \\
\text { diagnóstico da arborização urbana: o caso de } \\
\text { Macapá, Amapá }\end{array}$ & Castro, H.S., et al. & $R A^{\prime} E G A$ & 2016 & https://revistas.ufpr.br/raega/article/view/42281 \\
\hline $\begin{array}{l}\text { Análise quali-quantitativa da arborização de uma } \\
\text { praça urbana do norte do Brasil }\end{array}$ & Gomes, E.M.C., et al. & Nativa & 2016 & $\begin{array}{l}\text { http://periodicoscientificos.ufmt.br/ojs/index.php/ } \\
\text { nativa/article/view/3180/2642 }\end{array}$ \\
\hline $\begin{array}{l}\text { Diagnóstico florístico da praça Floriano Peixoto } \\
\text { NA cidade de Macapá, Amapá }\end{array}$ & Dantas, A.R., et al. & $\begin{array}{l}\text { Revista da Sociedade Brasileira de } \\
\text { Arborização Urbana }\end{array}$ & 2016 & https://revistas.ufpr.br/revsbau/article/view/63494 \\
\hline $\begin{array}{l}\text { Análise da composição florística de Boa Vista-RR: } \\
\text { subsídio para a gestão da arborização de ruas }\end{array}$ & $\begin{array}{l}\text { Lima Neto, E.M., } \\
\text { et al. }\end{array}$ & $\begin{array}{l}\text { Revista da Sociedade Brasileira de } \\
\text { Arborização Urbana }\end{array}$ & 2016 & https://revistas.ufpr.br/revsbau/article/view/63390 \\
\hline $\begin{array}{l}\text { Inventário da arborização urbana das principais } \\
\text { avenidas do município de Rorainópolis, Roraima }\end{array}$ & Veloso, J.N. & $\begin{array}{l}\text { Boletim do Museu Integrado de } \\
\text { Roraima }\end{array}$ & 2016 & $\begin{array}{l}\text { https://www.uerr.edu.br/bolmirr/wp-content/ } \\
\text { uploads/2016/11/BOLMIRR-v102-Veloso.pdf }\end{array}$ \\
\hline $\begin{array}{l}\text { Composição de espécies e índices arbóreos nos } \\
\text { pátios de três escolas de Gurupi-Tocantins }\end{array}$ & Batista, E.M.C., et al. & $\begin{array}{l}\text { Revista de estudos ambientais } \\
\text { (Online) }\end{array}$ & 2016 & $\begin{array}{l}\text { https://proxy.furb.br/ojs/index.php/rea/article/ } \\
\text { view/5796/3593 }\end{array}$ \\
\hline $\begin{array}{l}\text { Diagnóstico da arborização do parque urbano } \\
\text { Tucumã, em Rio Branco-AC }\end{array}$ & Santos, L.R., et al. & $\begin{array}{l}\text { Revista da Sociedade Brasileira de } \\
\text { Arborização Urbana }\end{array}$ & 2017 & https://revistas.ufpr.br/revsbau/article/view/63529 \\
\hline $\begin{array}{l}\text { Aspectos dendrométricos e qualitativos de Licania } \\
\text { tomentosa (Benth.) Fritsch na arborização urbana } \\
\text { de Itacoatiara, Amazonas }\end{array}$ & Gomes, I.B., et al. & Revista IGAPO & 2017 & $\begin{array}{l}\text { http://200.129.168.183/ojs/index.php/igapo/article/ } \\
\text { view/559/473 }\end{array}$ \\
\hline $\begin{array}{l}\text { Observational and experimental evaluation of } \\
\text { hemiparasite resistance in trees in the urban } \\
\text { afforestation of Santarém, Pará, Brazil }\end{array}$ & $\begin{array}{l}\text { Silva, F.P.; Fadini, } \\
\text { R.F. }\end{array}$ & Acta Amazonica & 2017 & $\begin{array}{l}\text { http: } \\
\text { //www.scielo.br/scielo.php?script=sci_arttext\& } \\
\text { pid=S0044-59672017000400311\&lng=en\&tlng=en }\end{array}$ \\
\hline $\begin{array}{l}\text { Diversidade florística e índices arbóreos de escolas } \\
\text { no município de Formoso do Araguaia, Tocantins }\end{array}$ & Santos, A.F., et al. & $\begin{array}{l}\text { Revista Verde de Agroecologia e } \\
\text { Desenvolvimento Sustentável }\end{array}$ & 2017 & $\begin{array}{l}\text { https://www.gvaa.com.br/revista/index.php/ } \\
\text { RVADS/article/view/4353 }\end{array}$ \\
\hline $\begin{array}{l}\text { Diagnóstico da arborização nas calçadas de } \\
\text { Gurupi, TO }\end{array}$ & Oliveira, L.M., et al. & $\begin{array}{l}\text { Revista da Sociedade Brasileira de } \\
\text { Arborização Urbana }\end{array}$ & 2017 & $\begin{array}{l}\text { https: } \\
\text { //revistas.ufpr.br/revsbau/article/view/63515/pdf }\end{array}$ \\
\hline $\begin{array}{l}\text { Estudo quali-quantitativo e percepção ambiental } \\
\text { da arborização do Setor Jardim Sevilha, Gurupi - } \\
\text { TO }\end{array}$ & $\begin{array}{l}\text { Wanderley, R.J.C., } \\
\text { et al. }\end{array}$ & $\begin{array}{l}\text { Revista da Sociedade Brasileira de } \\
\text { Arborização Urbana }\end{array}$ & 2017 & https://revistas.ufpr.br/revsbau/article/view/63579 \\
\hline $\begin{array}{l}\text { Inventário e análise da arborização nas calçadas da } \\
\text { região central de Gurupi-TO }\end{array}$ & Rabêlo, D., et al. & $\begin{array}{l}\text { Revista da Sociedade Brasileira de } \\
\text { Arborização Urbana }\end{array}$ & 2017 & https://revistas.ufpr.br/revsbau/article/view/63606 \\
\hline $\begin{array}{l}\text { Análise dos principais conflitos e espécies } \\
\text { inadequadas presentes na arborização viária na } \\
\text { região central do município de Imperatriz (MA) }\end{array}$ & Silva, R.V., et al. & $\begin{array}{l}\text { Revista da Sociedade Brasileira de } \\
\text { Arborização Urbana }\end{array}$ & 2018 & https://revistas.ufpr.br/revsbau/article/view/63656 \\
\hline
\end{tabular}


Table A2. Cont.

\begin{tabular}{|c|c|c|c|c|}
\hline Article titles & Authors & Journal & Year & Link to Access \\
\hline $\begin{array}{l}\text { Avaliação qualitativa da arborização com } \\
\text { Mangifera indica nas ruas de Belém - PA }\end{array}$ & Silva, D.A., et al. & Acta Biológica Catarinense & 2018 & $\begin{array}{l}\text { http: } \\
\text { //186.237.248.25/index.php/ABC/article/view/432 }\end{array}$ \\
\hline $\begin{array}{l}\text { Avaliação da organização árborea e a percepção } \\
\text { dos usuários das praças do município de } \\
\text { Mocajuba, Estado do Pará, Brasil }\end{array}$ & Barros, V.S., et al. & $\begin{array}{l}\text { Revista da Sociedade Brasileira de } \\
\text { Arborização Urbana }\end{array}$ & 2018 & https://revistas.ufpr.br/revsbau/article/view/63664 \\
\hline $\begin{array}{l}\text { Diagnóstico visual e fitossociologia na arborização } \\
\text { de praças em Paragominas, Pará }\end{array}$ & Silva, I.R., et al. & $\begin{array}{l}\text { Revista da Sociedade Brasileira de } \\
\text { Arborização Urbana }\end{array}$ & 2018 & https://revistas.ufpr.br/revsbau/article/view/63567 \\
\hline $\begin{array}{l}\text { Use of morphometry in the arborization of } \\
\text { Paragominas city, Pará, Brazil, with Handroanthus } \\
\text { impetiginosus (Mart. ex DC.) Mattos (Bignoniaceae) }\end{array}$ & Oliveira, V.P., et al. & RevistaAgro@mbiente On-Line & 2018 & $\begin{array}{l}\text { https: } \\
\text { //revista.ufrr.br/agroambiente/article/view/4975 }\end{array}$ \\
\hline $\begin{array}{l}\text { Arborização urbana com nim indiano na cidade de } \\
\text { Santarém, Pará, Brasil }\end{array}$ & Dantas, R.C.O., et al. & $\begin{array}{l}\text { Revista da Sociedade Brasileira de } \\
\text { Arborização Urbana }\end{array}$ & 2018 & https://revistas.ufpr.br/revsbau/article/view/63643 \\
\hline $\begin{array}{l}\text { Diagnóstico da arborização urbana da cidade de } \\
\text { Vitória do Xingu, Pará, Brasil }\end{array}$ & Silva, L.A., et al. & $\begin{array}{l}\text { Revista da Sociedade Brasileira de } \\
\text { Arborização Urbana }\end{array}$ & 2018 & $\begin{array}{l}\text { https: } \\
\text { //revistas.ufpr.br/revsbau/article/view/63622/pdf }\end{array}$ \\
\hline $\begin{array}{l}\text { Caracterização quantitativa da arborização urbana } \\
\text { no município de Itapuã Do Oeste/RO-Brasil }\end{array}$ & Rocha, C.L.D., et al. & Revista Saber Científico & 2018 & $\begin{array}{l}\text { http://revista.saolucas.edu.br/index.php/resc/ } \\
\text { article/view/764 }\end{array}$ \\
\hline $\begin{array}{l}\text { Colonização por cupins (Isoptera) da arborização } \\
\text { urbana e implicações socioambientais em Porto } \\
\text { Velho, Rondônia }\end{array}$ & $\begin{array}{l}\text { Santos Junior, A.; } \\
\text { Sampaio, F.T.S. }\end{array}$ & $\begin{array}{l}\text { Boletim do Observatório Ambiental } \\
\text { Alberto Ribeiro Lamego }\end{array}$ & 2018 & $\begin{array}{l}\text { http://www.essentiaeditora.iff.edu.br/index.php/ } \\
\text { boletim/article/view/10024/9140 }\end{array}$ \\
\hline $\begin{array}{l}\text { Impacto da implantação do BRT na arborização da } \\
\text { região central de Palmas, Tocantins }\end{array}$ & Pinheiro, R.T., et al. & Desenvolvimento e Meio ambiente & 2018 & https://revistas.ufpr.br/made/article/view/55981 \\
\hline $\begin{array}{l}\text { Levantamento quali-quantitativo da arborização } \\
\text { urbana no município de Buriticupu, MA }\end{array}$ & Sousa, L.A., et al. & $\begin{array}{l}\text { Revista da Sociedade Brasileira de } \\
\text { Arborização Urbana }\end{array}$ & 2019 & https://revistas.ufpr.br/revsbau/article/view/65372 \\
\hline $\begin{array}{l}\text { Silvicultura urbana: levantamento e caracterização } \\
\text { da arborização em uma área central na cidade de } \\
\text { Cáceres-MT }\end{array}$ & Santos, C.T.F., et al. & Scientia Tec & 2019 & $\begin{array}{l}\text { https://periodicos.ifrs.edu.br/index.php/ } \\
\text { ScientiaTec/article/view/3194 }\end{array}$ \\
\hline $\begin{array}{l}\text { Composição florística e fitossanidade das praças } \\
\text { Barão e Liberdade, Santarém, Pará }\end{array}$ & Pires, O.V., et al. & $\begin{array}{l}\text { Revista Ibero-Americana de } \\
\text { Ciências Ambientais }\end{array}$ & 2019 & $\begin{array}{l}\text { http://www.sustenere.co/index.php/rica/article/ } \\
\text { view/3121 }\end{array}$ \\
\hline $\begin{array}{l}\text { Espécies arbóreas tóxicas presentes na arborização } \\
\text { urbana do município de Santarém, Pará }\end{array}$ & $\begin{array}{l}\text { Baumann, S.S.R.T., } \\
\text { et al. }\end{array}$ & $\begin{array}{l}\text { Revista Ibero-Americana de } \\
\text { Ciências Ambientais }\end{array}$ & 2019 & http://sustenere.co/index.php/rica/issue/view/155 \\
\hline $\begin{array}{l}\text { Espécies frutíferas na arborização urbana do } \\
\text { município de Santarém, Pará }\end{array}$ & Rabelo, L.K.L., et al. & $\begin{array}{l}\text { Revista Ibero-Americana de } \\
\text { Ciências Ambientais }\end{array}$ & 2019 & $\begin{array}{l}\text { http: } \\
\text { //sustenere.co/index.php/rica/article/view/3097 }\end{array}$ \\
\hline $\begin{array}{l}\text { Arborização das praças de Gurupi - TO - Brasil: } \\
\text { composição e diversidade de espécies }\end{array}$ & Silva, A.D.P., et al. & $\begin{array}{l}\text { Revista da Sociedade Brasileira de } \\
\text { Arborização Urbana }\end{array}$ & 2019 & https://revistas.ufpr.br/revsbau/article/view/67547 \\
\hline
\end{tabular}




\section{References}

1. Trindade Júnior, S.C.C. Cidades na floresta: Os "grandes objetos" como expressões do meio técnico-científico informacional no espaço amazônico. Rev. Inst. Estud. Bras. 2010, 50, 113-138. [CrossRef]

2. Salbitano, F.; Borelli, S.; Conigliaro, M.; Chen, Y. Guidelines on Urban and Peri-Urban Forestry; FAO: Rome, Italy, 2016.

3. Padoch, C.; Brondizio, E.; Costa, S.; Pinedo-Vasquez, M.; Sears, R.R.; Siqueira, A. Urban forest and rural cities: Multi-sited households, consumption patterns, and forest resources in Amazonia. Ecol. Soc. 2008, 13, 2. [CrossRef]

4. Narducci, J.; Quintas-Soriano, C.; Castro, A.; Som-Castellano, R.; Brandt, J.S. Implications of urban growth and farmland loss for ecosystem services in the western United States. Land Use Policy 2019, 86, 1-11. [CrossRef]

5. Figueiredo, S.L.; Ravena, N. Cidades, fronteiras e diversidades na Amazônia. R. B. Estud. Urbanos E Reg. 2014, 16, 241-246. [CrossRef]

6. O’Brien, L.; De Vreese, R.; Atmis, E.; Olafsson, A.S.; Sievänen, T.; Brennan, M.; Sánchez, S.; Panagopoulos, T.; de Vries, S.; Kern, M.; et al. Social and Environmental Justice: Diversity in Access to and Benefits from Urban Green Infrastructure-Examples from Europe. In The Urban Forest; Springer: Cham, Switzerland, 2017; pp. 153-190. [CrossRef]

7. Morgenroth, J.; Östberg, J.; van den Bosch, C.K.; Nielsen, A.B.; Hauer, R.; Sjöman, H.; Chen, W.; Jansson, M. Urban tree diversity-Taking stock and looking ahead. Urban For. Urban Green. 2016, 15, 1-5. [CrossRef]

8. Nero, B.F.; Kwapong, N.A.; Jatta, R.; Fatunbi, O. Tree species diversity and socioeconomic perspectives of the urban (food) forest of Accra, Ghana. Sustainability 2018, 10, 3417. [CrossRef]

9. Nilsson, K.; Randrup, T.B.; Wandall, B.M. Trees in the Urban Environment. In The Forests Handbook; Evans, J., Ed.; Wiley-Blackwell: Hoboken, NJ, USA, 2008. [CrossRef]

10. Terkenli, S.T.; Zivojinovic, I.; Tomićević-Dubljević, J.; Panagopoulos, T.; Straupe, I.; Toskovic, O.; Kristianova, K.; Straigyte, L.; O’Brien, L.; Bell, S. Recreational Use of Urban Green Infrastructure: The Tourist's Perspective. In The Urban Forest; Pearlmutter, D., Calfapietra, C., Samson, R., O’Brien, L., Krajter Ostoić, S., Sanesi, G., Alonso del Amo, R., Eds.; Springer: Cham, Switzerland, 2017; pp. 191-216. [CrossRef]

11. Cardoso, S.L.C.; Figueiredo, S.L. Arquitetura Ecológica: Modelos paisagísticos, requalificação e refuncionalização de espaços públicos verdes urbanos. Paisagens Híbridas 2018, 2, 34-53.

12. Rowntree, R.A.; Nowak, D.J. Quantifying the role of urban forests in removing atmospheric carbon dioxide. J. Arboric. 1991, 17, 269-275.

13. FAO_Food and Agriculture Organization of the United Nations. Benefits of Urban Trees. Available online: http://www.fao.org/3/a-c0024e.pdf (accessed on 10 February 2020).

14. Yan, P.; Yang, Y. Species diversity of urban forests in China. Urban For. Urban Green. 2017, 28, $160-166$. [CrossRef]

15. Thomsen, P.; Bühler, O.; Kristoffersen, P. Diversity of street tree populations in larger Danish municipalities. Urban For. Urban Green. 2016, 15, 200-210. [CrossRef]

16. Staudhammer, C.L.; Escobedo, F.J.; Blood, A. Assessing methods for comparing species diversity from disparate data sources: The case of urban and peri-urban forests. Ecosphere 2018, 9, e02450. [CrossRef]

17. Pereira, H.S.; Kudo, S.A.; Silva, S.C.P. Topophilia and environmental valuation of urban forest fragments in an Amazonian city. Ambiente Soc. 2018, 21, e01590. [CrossRef]

18. IBGE-Instituto Brasileiro de Geografia e Estatísticas. População Estimada; Ibge/DPE/Copis: Rio de Janeiro, Brazil, 2019.

19. IBGE-Instituto Brasileiro de Geografia e Estatísticas. Área da Unidade Territorial: Área terriTorial Brasileira; Ibge/DPE/Copis: Rio de Janeiro, Brazil, 2019.

20. IBGE-Instituto Brasileiro de Geografia e Estatísticas. PIB per Capita-2017; Ibge: Rio de Janeiro, Brazil, 2017.

21. IBGE-Instituto Brasileiro de Geografia e Estatísticas. Arborização de Vias Públicas; Ibge: Rio de Janeiro, Brazil, 2010.

22. IBGE-Instituto Brasileiro de Geografia e Estatísticas. Urbanização de Vias Públicas; Ibge: Rio de Janeiro, Brazil, 2010. 
23. PNUD—Programa das Nações Unidas para o Desenvolvimento. Ranking IDHM Municípios 2010—Brasil. Available online: https:/www.br.undp.org/content/brazil/pt/home/idh0/rankings/idhm-municipios-2010. html (accessed on 20 December 2019).

24. Denatran-Departamento Nacional de Trânsito. Frota de veículos—2018; Departamento Nacional de Trânsito: Denatran, Brasília, 2018.

25. Inmet-Instituto Nacional de Meteorologia. Estação Meteorológica de Observação de Superfície Automática; Inmet: Madrid, Brasília, 2019.

26. Magurran, A.E. Ecological Diversity and its Measurement; British Library: Cambridge, UK, 1988; 179p.

27. Almeida, D.N.; Rondon Neto, R.M. Análise da arborização urbana de três cidades da região norte do Estado de Mato Grosso. Acta Amaz. 2010, 40, 647-656. [CrossRef]

28. Parry, M.M.; Silva, M.M.; Sena, I.S.; Oliveira, F.P.M. The floristic composition of urban afforestation of the city Altamira, Pará State, Brazil. Revsbau 2012, 7, 143-158. [CrossRef]

29. R Core Team. R. A language and environment for statistical computing; R Foundation for Statistical Computing: Vienna, Austria, 2018; Available online: http://www.R-project.org/ (accessed on 7 June 2019).

30. Congresso Nacional. Constituição da República Federativa do Brasil; Congresso Nacional: Brasília, Brazil, 1988.

31. Asnake, M. The importance of scientific publication in the development of public health. Ciênc. saúde coletiva. 2015, 20, 1972-1973. [CrossRef]

32. Liu, C.; Li, X. Carbon storage and sequestration by urban forests in Shenyang, China. Urban For. Urban Green. 2012, 11, 121-128. [CrossRef]

33. Dantas, R.C.O.; Bezerra, T.G.; Vieira, T.A. Arborização urbana com nim indiano na cidade de Santarém, Pará, Brasil. Revsbau 2018, 13, 37-46. [CrossRef]

34. Almeida, D.N.; Rondon Neto, R.M. Análise da arborização urbana de duas cidades da região norte do estado de Mato Grosso. Revista Árvore 2010, 34, 899-906. [CrossRef]

35. Lima de Medeiros, J.; Almeida, T.S.; Neto, J.J.L.L.; Almeida Filho, L.C.P.; Ribeiro, P.R.V.; Brito, E.S.; Morgano, M.A.; Gomes da Silva, M.; Farias, D.F.; Carvalho, A.F.U. Chemical composition, nutritional properties, and antioxidant activity of Licania tomentosa (Benth.) fruit. Food Chem. 2020, 313, 126117. [CrossRef]

36. Assunção, K.C.; Luz, P.B.; Neves, L.G.; Sobrinho, S.P. Quantitative survey of afforestation of squares in the city of Cáceres, Mato Grosso State, Brazil. Revsbau 2014, 9, 115-124. [CrossRef]

37. Araújo, A.C.B.; Gracioli, C.R.; Grimm, E.L.; Longhi, S.J. The assessment of floristic composition, size, health and current tree conservation of the International Park in Sant'ana do Livramento Brazil and Rivera Uruguay. Revsbau 2012, 7, 66-74. [CrossRef]

38. Santamour, F.S., Jr. Trees for Urban Planting: Diversity, Uniformity, and Common Sense. In Proceedings of the 7th Conf. Metropolitan Tree Improvement Alliance (METRIA), Lisle, IL, USA, 11-12 June 1990; pp. 57-65.

39. Porto, L.P.M.; Brasil, H.M.S. Manual de Orientação Técnica da Arborização Urbana de Belém: Guia para Planejamento, Implantação e Manutenção da Arborização em Logradouros Públicos; UFRA: Belém, Brasil, 2013.

40. Gomes, E.M.C.; Rodrigues, D.M.S.; Santos, J.T.; Barbosa, E.J. Análise quali-quantitativa da arborização de uma praça urbana do Norte do Brasil. Nativa 2016, 4, 179-186. [CrossRef]

41. Silva, L.A.; Sousa, C.S.; Parry, M.M.; Herrera, R.C.; Oliveira, F.P.M.; Parry, S.M. Diagnóstico da arborização urbana da cidade de Vitória do Xingu, Pará, Brasil. Revsbau 2018, 13, 57-72. [CrossRef]

42. Dantas, A.R.; Gomes, E.M.C.; Pinheiro, A.P. Diagnóstico florístico da Praça Floriano Peixoto na cidade de Macapá, Amapá. Revsbau 2016, 11, 32-46. [CrossRef]

43. Moro, M.F.; Westerkamp, C.; Araújo, F.S. How much importance is given to native plants in cities' treescape? A case study in Fortaleza, Brazil. Urban For. Urban Green. 2014, 13, 365-374. [CrossRef]

44. Sousa, L.A.; Cajaiba, R.L.; Martins, J.S.C.; Colácio, D.S.; Sousa, E.S.; Pereira, K.S. Levantamento quali-quantitativo da arborização urbana no município de Buriticupu, MA. Revsbau 2019, 14, 42-52. [CrossRef]

45. Moro, M.F.; Westerkamp, C. The alien street trees of Fortaleza (NE Brazil): Qualitative observations and the inventory of two districts. Ciência Florest. 2011, 21, 789-798. [CrossRef]

46. de Paiva, A.V.; Lima, A.B.M.; Carvalho, A.; Junior, A.M.; Gomes, A.; Melo, C.S.; Farias, C.O.; Reis, C.; Bezerra, C.; Junior, E.A.; et al. Inventário e diagnóstico da arborização urbana viária de Rio Branco, AC. Revsbau 2010, 5, 144-159. [CrossRef]

47. Blum, C.T.; Borgo, M.; Sampaio, A.C.F. Espécies exóticas invasoras na arborização de vias públicas de Maringá-PR. Revsbau 2008, 3, 78-97. [CrossRef] 
48. Maranho, A.S.; de Paula, S.R.P.; Lima, E.; Paiva, A.V.; Alves, A.P.; Nascimento, D.O. Levantamento censitário da arborização urbana viária de Senador Guiomard, Acre. Revsbau 2012, 7, 44-56. [CrossRef]

49. Gomes, I.B.; Pinto, L.A.A. Aspectos dendrométricos e qualitativos de Licania tomentosa (Benth.) Fritsch na arborização urbana de Itacoatiara, Amazonas. Igapó 2017, 11, 35-46.

50. Castro, H.S.; Dias, T.C.A.C.; Amanajás, V.V.V. A geotecnologia como ferramenta para o diagnóstico da arborização urbana: O caso de Macapá, Amapá. Raega-O Espaço Geográfico Em Análise 2016, 38, 146-168. [CrossRef]

51. Ferro, C.C.S.; Oliveira, R.S.; Andrade, F.W.C.; Souza, S.M.A.R. Inventário quali-quantitativo da arborização viária de um trecho da rodovia PA-275 no município de Parauapebas-PA. Revsbau 2015, 10, 73-84. [CrossRef]

52. Santos, L.C.; Santos, E.A.; Pinheiro, R.M.; Ferreira, E.J.L. Diagnóstico da arborização do parque urbano tucumã, em Rio Branco-AC. Revsbau 2017, 12, 103-117. [CrossRef]

53. Pires, O.V.; Araújo, N.M.; Silva, J.R.P.; Bonfim, M.C.S.; Sousa, S.F.; Maestri, M.P. Composição florística e fitossanidade das praças Barão e Liberdade, Santarém, Pará. Rev. Ibero Am. De Ciências Ambient. 2019, 10, 228-237. [CrossRef]

54. Silva, D.A.; Batista, D.B.; Batista, A.C. Avaliação qualitativa da arborização com Mangifera indica nas ruas de Belém-PA. Acta Biológica Catarin. 2018, 5, 34-45. [CrossRef]

55. Castillo Rodríguez, L.C.; Pastrana Falcón, J.C. Diagnóstico del arbolado viario de El Vedado: Composición, distribución y conflictos. Arquit. Y Urban. 2015, 36, 92-118.

56. Silva, O.H.; Locastro, J.K.; Sanches, S.P.; Angelis Neto, G.; Angelis, B.L.D.; Caxambú, M.G. Avaliação da arborização viária da cidade de São Tomé, Paraná. Ciência Florest. 2019, 29, 371-384. [CrossRef]

57. Wilson, J.; Tyedmers, P.; Pelot, R. Contrasting and comparing sustainable development indicator metrics. Ecol. Indic. 2007, 7, 299-314. [CrossRef]

58. Du Toit, M.J.; Cilliers, S.S.; Dallimer, M.; Goddard, M.; Guenat, S.; Cornelius, S.F. Urban green infrastructure and ecosystem services in sub-Saharan Africa. Landsc. Urban Plan. 2018, 18, 249-261. [CrossRef]

59. Akerlund, U.; Knuth, L.; Randrup, T.B.; Schipperijn, J. Urban and Peri-Urban Forestry and Greening in West and Central Asia-Experiences, Constraints and Prospects. LSP Working Paper 36 Access to Natural Resources Sub-Programme. 2006. Available online: http://www.fao.org/3/a-ah238e.pdf (accessed on 20 December 2019).

60. De Sousa Silva, C.; Viegas, I.; Panagopoulos, T.; Bell, S. Environmental justice in accessibility to green infrastructure in two European cities. Land 2018, 7, 134. [CrossRef]

61. Dobbs, C.; Nitschke, C.R.; Kendal, D. Global drivers and tradeoffs of three urban vegetation ecosystem services. PLoS ONE 2014, 9, e113000. [CrossRef] [PubMed]

62. Hope, D.; Gries, C.; Zhu, W.; Fagan, W.F.; Redman, C.L.; Grimm, N.B.; Nelson, A.L.; Martin, C.; Kinzig, A. Socioeconomics drive urban plant diversity. Proc. Natl. Acad. Sci. USA 2003, 22, 8788-8792. [CrossRef] [PubMed]

63. Terkenli, T.; Bell, S.; Toskovic, O.; Tomicevic, J.D.; Panagopoulos, T.; Straupe, I.; Kristianova, K.; Staigyte, L.; 'O'Brien, L.; Zivozjinovic, I. Tourist perceptions and uses of urban green infrastructure: An exploratory cross-cultural investigation. Urban For. Urban Green. 2020, 49, 126624. [CrossRef]

(C) 2020 by the authors. Licensee MDPI, Basel, Switzerland. This article is an open access article distributed under the terms and conditions of the Creative Commons Attribution (CC BY) license (http://creativecommons.org/licenses/by/4.0/). 